\title{
Complaints: pathology or talking cure?
}

\author{
Ann Abraham
}

UK Parliamentary Ombudsman and Health Service Ombudsman for England

A recent conference organised by the Royal College of Physicians in London took as its theme the notion of 'multiple medico-legal jeopardy'. Its purpose was to explore the implications for doctors of their 'multiple accountability', ranging from professional disciplinary proceedings to professional negligence claims and, in extreme circumstances, even criminal charges. The implicit assumption was that 'multiple accountability' of this sort is not only unfair but also potentially counterproductive: too much accountability simply leads to defensive practice and impoverished service delivery to patients.

My experience as UK Parliamentary Ombudsman and Health Service Ombudsman for England suggests otherwise. It is certainly true that my office sits at the pinnacle of a rather diffuse health-service complaints pyramid. To that extent, its very existence might be seen as yet another level of 'jeopardy', a final trap to be avoided in a perennial game of professional snakes and ladders. Such a view, however, betrays a misunderstanding both of the act of complaining and of the role of the Ombudsman.

It is tempting to think of complaining as an irritating form of weakness or even of personal psychopathology. Yet, at its best, complaining is rooted not in self-interest or a false sense of self-importance but in the recognition of things being out of order and of their needing to be put right. Complaining has a noble modern history, from Emmeline Pankhurst to Martin Luther King and Nelson Mandela. However, just as the severity of a medical complaint should be measured not by how loudly it draws attention to itself but by the extent to which the mind and body really are damaged, so we should not mistake the loudness of a complaint for its importance. It is with complaints that really do express the sense of 'mind and body damaged' that I am most concerned, not least because such complaints, when directed at the quality of healthcare, contain within them a vision of what 'the mind and body', in this instance healthcare services, should look like when in proper working order.

In England, the government has recently developed a constitution for the National Health Service, which establishes the principles and values of the Service and provides a useful vision of the healthcare 'mind and body' when in good working order. Its distinguishing characteristic is the desire to put the individual at the centre of things. That desire is given expression in a number of references to 'respect', 'dignity' and 'compassion' and in the assertion that 'everyone counts'. It is present also in the aspiration to 'work together' for patients and to 'improve lives'. This is not, as I see it, a technocratic vision of targets, mechanised systems and impersonal efficiency. Of course, excellence and professionalism are part and parcel of the vision, but they are presented very much as a means to an end, and not as technical ends in themselves.
That recognition of the primacy of the individual is, I would suggest, where the Ombudsman comes in. The role of Ombudsman originated in Sweden in 1809. At the very heart of the Ombudsman concept, as originally imported from Scandinavia, is the idea of 'lay' oversight, of being a representative of ordinary people, of seeing things from their perspective, unencumbered by all the misperceptions that can go with too much specialised experience and too much arcane expertise. The danger of a too narrowly focused expertise is, of course, that we can end up missing the wood for the trees.

Conversely, the task of seeing the wood and not being overwhelmed by the beauty and intricacy of the individual trees - the task, in other words, of an Ombudsman - is all about the bigger picture afforded by seeing the patient as an individual and medical intervention as part of a whole range of social factors that make up the complex possibilities of well-being.

It is the need to keep that bigger picture in view that has led to an important initiative in my office over the past couple of years: the production of a trilogy of basic principles governing our work with public authorities. The trilogy comprises concise statements of principle in respect of good administration, of remedy and of complaints handling. These are not rules of the sort you might expect a court to be concerned with. They do not prescribe desirable behaviour in any detail, nor do they tailor their application to particular sectors. The key principles outlined are these:

getting it right

O being customer focused

O being open and accountable

$O$ acting fairly and proportionately

o putting things right

O seeking continuous improvement.

These key principles of legality, flexibility, transparency, fairness and accountability are, if you like, my rule of thumb for evaluating the performance of public authorities, including those in the healthcare sector. They underpin my assessment of performance, my approach to remedy and my vision of good complaints handling. Other Ombudsmen, both within the UK and internationally, will apply similar standards to the public authorities they oversee.

Does this Ombudsman intrusion then represent an example of 'multiple jeopardy'? Certainly, it might be seen that way, since it is perfectly possible for a health authority to resist a claim of professional negligence yet find itself on the wrong side of a finding by the Ombudsman. To that extent, there is no escape. But there is a big difference between an Ombudsman's findings and those of a court or of a professional association, for example. And that big difference is that, at the end of an investigation, an Ombudsman, typically, does not make a final enforceable judgement 
that must be complied with for fear of legal consequences. Instead, an Ombudsman makes recommendations, which may or may not be complied with. Naturally, my fellow Ombudsmen and I expect that in most cases our recommendations will be complied with, and in fact in $99 \%$ of cases that expectation turns out to be justified. Nevertheless, it remains open to a public authority to refuse and to face the music instead. The Ombudsman has, to put it in the jargon, a 'mandate of influence' rather than a 'mandate of sanction'.

A mandate of influence of this sort can, outside the legal or disciplinary process, work very effectively in practice. In one recent case investigated by my office, a staff-grade psychiatrist for older people decided to withdraw an antidementia drug from an elderly patient. My investigation uncovered a failure to communicate significant changes in the patient's treatment plan to those members of the family most closely involved in the patient's care, and the omission of any planning for deterioration. This was not a case of the clinical decision itself being wrong, but rather of a failure to see the bigger picture of which that clinical decision formed just one part. As a result, the trust in question agreed to apologise to the patient and family and to remind senior medical staff of the importance of careful monitoring of patients where medication is discontinued. The trust also agreed to conduct an audit of 'consensus-meeting documentation' to ensure that this format was properly used in future and that the requisite level of information was recorded.

Another case concerned the treatment of an adolescent girl with anorexia nervosa, who regularly absconded from hospital and whose parents despaired of the level of treatment offered to her, even to the extent of removing her to private care after 18 months with the National Health Service. My investigation found that the adolescent unit had inadequate systems in place for care planning, communication, risk assessment and risk management. These omissions denied the patient and her family any real sense of engagement in her treatment. As a result, she lost weight and her health and safety were compromised. The trust in question apologised, paid compensation for distress and reimbursed the full cost of the private treatment incurred. Just as importantly, the trust also ensured that it would in future have clear policies that could be shared with patients and their families, and that it would implement the latest national clinical guidelines on eating disorders.

These examples reinforce my view that exposure to complaints should not be a source of professional trepidation. The process of complaining should instead be seen as part of the necessary dialogue between patient, professional healthcare staff and the healthcare 'system' as a whole. It is, in other words, part of the process for diagnosing the state of those healthcare services and prescribing the proper remedial treatment. At its best, it is nothing less than a 'talking cure' in action, the Ombudsman cast in the role more of therapist than of judge. Which is not to say that there will not be a place for 'tough love' on occasions. But it is to say that the whole business is ultimately about a shared quest for excellence much more than the unilateral ascription of individual blame.

\section{Mental health and poverty}

\section{David Skuse}

Behavioural and Brain Sciences Unit, Institute of Child Health, London WC1N 1EH, UK, email dskuse@ich.ucl.ac.uk

W e are all too well aware that there is a link between poverty and mental health in the Western world, which can work in two directions: those with low incomes are more likely to suffer from poor mental health; and people with mental health problems are more likely to experience poverty. In this issue, we consider the link between poverty and mental health from the perspectives of the Caribbean, East Africa and Mexico. In each situation, the relationship between them is complex and dynamic.

Fred Hickling challenges us to consider the possibility that the legacy of colonial rule in the Caribbean has led to a political and economic system that ignores the potential contribution of its most talented citizens, and which engenders a sense of helplessness and hopelessness that can lead to violent crime and mental disorder. Those who escape from this legacy (the so-called Caribbean Diaspora) find little comfort in their hoped-for paradise in Europe or the United States, and are at greater risk of developing mental illness there than is the indigenous population. He concludes that 'poverty has become too costly to maintain for any society' a challenging view indeed.

Fred Kigozi and Joshua Ssebunnya draw our attention to the troubles of East Africa (that cluster of countries around Lake Victoria). In an area of 130 million $\mathrm{km}^{2}$, there are fewer than a dozen psychiatrists. The population is growing rapidly and poverty is increasing. In the countries comprising this region, there have been and continue to be terrible wars and internal conflicts - especially in Rwanda and Uganda. To make matters worse, refugees from beyond their borders are coming in. Not surprisingly, many of these refugees have major mental health problems associated with their experiences and the trauma of dislocation. Objective evidence 